DOI 10.37882/2223-2982.2021.04.35

\title{
ЛИНГВОЭКОЛОГИЧНОСТЬ ЯЗЫКА И РЕЧИ: АНГЛИЦИЗМЫ В ИНТЕРНЕТ-РЕКЛАМЕ
}

\section{LINGUOECOLOGY OF LANGUAGE AND SPEECH: ANGLICISMS IN INTERNET-ADVERTISING}

\section{Tsaturyan \\ A. Matevosyan}

Summary: The article is devoted to the problems of linguoecology of language and speech. The relevance of the proposed topic is due to the study of various linguistic phenomena in virtual discourse. The study of English borrowings in internet advertising is carried out on the example of real text messages in internet advertising and the social network Twitter. Anglicization negatively affects other languages and can lead to their demise.

Keywords: ecology of language and speech, internet advertising, anglicisms, linguistic and ecological crisis.
Цатурян Марина Мартиросовна

Д.филол.н., профессор, Кубанский государственный университет (Краснодар)

tsaturyan.mm@mail.ru

Матевосян Ареват Паруйровна

Соискатель, Кубанский государственный университет

(Краснодар)

arevik.matevosyan.85@mail.ru

Аннотация: Статья посвящена рассмотрению проблем лингвоэкологии языка и речи. Актуальность предложенной темы обусловлена изучением различных языковых явлений в виртуальном дискурсе. Исследование английских заимствований в интернет-рекламе проводится на примере реальных текстовых сообщений интернет-рекламы и социальной сети Twitter. Англизация отрицательно влияет на другие языки и может стать причиной их гибели.

Ключевые слова: экология языка и речи, интернет-реклама, англицизмы, лингвоэкологический кризис.

сохранению этой среды как единого целого.

Лингвоэкология, как новая отрасль языкознания, позволяет разграничить понятия экологичности и неэкологичности, осмыслить феномен обращения в данном аспекте для определения успешности вербального и социального взаимодействия коммуникантов. Отмечается, что теоретическая разработка учения о лингвоэкологичности общения как сравнительно нового направления в лингвистике, а также связанного с ним терминологического аппарата пока еще находится в стадии формирования. В ходе изучения проблем лингвоэкологии установлено, что исследования в области лингвоэкологичности тесно связаны с такими понятиями, как нормализация, кодификация, речевой этикет, эстетичность, этичность, вежливость, невежливость, агрессия, речевая погрешность, коммуникативное давление, тональность, коммуникабельность, взаимопонимание, коммуникативная толерантность, деструктивная толерантность, коммуникативное смягчение, коммуникативный успех, искренность, лицемерие, истинность, ментальность, менталитет. Данные понятия, отражающие созидательный или деструктивный характер общения, являются основополагающими в анализе модели лингвоэкологии. Изучение лингвоэкологической терминологии обусловлено необходимостью создания собственной понятийной системы новой отрасли языкознания с целью признать ее самостоятельным научным направлением. Термин «эколингвистика», как пишет С.В. Ионова, был введен 
в научный оборот американским лингвистом Э. Хаугеном [Ионова 2010]. Его считают родоначальником понятия экологии языка и основателем теории экологии языка. Экологию языка Хауген определяет как исследование взаимодействий между любым данным языком и его окружающей средой, которой является общество, использующее этот язык как один из своих кодов [Haugen 1972].

Составляющими экологического портрета языка являются: количество носителей языка; сферы его функционирования; внутренняя стратификация языка; наличие кодификации; вербализация в языке моральноэтических концептов; негативно влияющие на развитие языка факторы и т.д. Этот перечень является далеко не полным и требует дальнейшей разработки, поскольку в понятии экологического портрета должны быть сконцентрированы все основные проблемы экологичности языка. На основании экологического портрета возможна разработка системы лингвоэкологической безопасности, направленной на охрану и развитие языка. Одна из задач такой системы - «предотвратить проникновение отрицательного узуса в систему, предотвратить регресс языка в плане обеднения его выразительных ресурсов, нивелирования функционально - стилистических и аксиологических оппозиций» [Бернацкая 2003:122]. По мнению Э. Хаугена, можно вывести статус языка в типологии экологической классификации, которая покажет, где находится язык и куда движется в сравнении с другими языками мира [Haugen 1972].

В наше время происходит «смещение коммуникации в сторону неэкологичности» [Солодовникова, Шаховский 2012], что подтверждается «экологическими бедствиями» например такими, как наплыв иноязычных слов, стилистическое снижение речи, ее жаргонизация, вульгаризация, штампованность, употребление нецензурных слов и выражений, пренебрежение формулами вежливости, оскуднение лексикона носителей языка. Причем названное смещение отражается в используемых учеными терминах, например: «речевая безответственность» [Линчевский 2006:78], «загрязнение речевой среды» [Сидоренко, Гаврилова 2013: 108], «огрубление речи» [Церцвадзе 2013: 18], «коэффициент загрязненности речи (текста)», «речевая дигрессия» [Коровушкин 2011:60], «речевое убийство», «речевое хулиганство», «речевое воровство» [Огдонова 2009: 122], «речевая нечистоплотность» [Чернышов и др. 2011: 69], «речевое запугивание» [Белозерева, Лабунец 2012: 11] и др.

Одновременно возрастает интерес к родным языкам, появляется желание охранять свои языки от иноязычных влияний, ярким примером может служить Франция со своим законом Тубона по защите француз- ского языка в связи с нарастающим проникновением англицизмов, в том числе в язык документов госучреждений (1994), а также Польша с принятым в 1999 году польским сеймом «Законом в защиту польского языка». Усиливают свои позиции организации по борьбе за чистоту языка, например, Общество немецкого языка (Германия), Королевская академия испанского языка (Испания), создаются программы по поддержке национальных языков (отметим Европейскую хартию региональных языков), государство разрабатывает соответствующие законы.

Поскольку любой язык подвержён постоянным изменениям, неправомерно считать, что иноязычные, а в контексте глобализации конца XX - начала XXI вB. англоязычные заимствования, отрицательно влияют на другие языки или могут стать причиной их гибели. Важнейшим результатом глобализации следует назвать не языковое влияние англицизмов само по себе, а возникновение некоей элиты, ориентированной на глобальное, её культурное отдаление от других и, как следствие, возникающая социальная поляризация. Английский язык в контексте lingua franca символизирует власть и, возможно, с этим связан тот факт, что усилия по борьбе с англоязычными заимствованиями, прилагаемые пуристами, безрезультатны, поскольку они направлены не на первопричину.

Мы проанализировали влияние английского языка на язык русской интернет-рекламы, а также вопросы фиксации англоязычных заимствований в словаре общего языка и специализированном справочнике англоязычных заимствований. Межъязыковые заимствования можно считать непосредственным следствием унификации и универсализации как составляющих глобализации. Они проникают, в первую очередь, в такие сферы общеупотребительного языка-реципиента как новейшие технологии, средства массовой информации, мода, кино и телепроизводство, спорт, в специальные языки молодежи, в рамках сотрудничества со странами НАТО в язык военных и конечно, в интернет-рекламу.

Интернет-рекламу называют одним из путей, через который англицизмы попадают в русский язык. Опираясь на положительные ассоциации и ценности, связываемые с английским языком, специалисты по рекламе способствуют сбыту товаров. Несмотря на то, что англицизмы не всегда точно понимаются гражданами России, а также, несмотря на наличие традиционных русскоязычных областей в рекламе, английский язык продолжает оказывать значительное влияние на язык русской рекламы. Англоязычные заимствования встречаются преимущественно в заголовках и самих рекламных текстах, связанных с новейшими технологиями, с индустрией моды и красоты, кино и телепроизводством, автомобильной промышленностью. 
Большинство англицизмов, которые очень часто употребляются в рекламе для точной передачи информации, не имеют альтернативного перевода в русском языке. Так, например:

Джинсы от англ: jeans

«Голубые джинсы самая главная покупка будущей весны» (твит от 13 февраля 2021 года)

Чйсы от англ: chips

«LAY'S Pифленые-чипсы, каждая пачка которых изготовлена из отборного картофеля и соответствует самым высоким стандартам качества. Рифленая текстура золотистой отборной картошки, нежный и насыщенный вкус - вот, что нужно в моменты истинного наслаждения!» Электронный ресурс: [https:// www.lays.ru]

Ancaйклинг om англ: upcycling - это тренд, позволяющий вещам прожить еще одну жизнь, подразумевая вторичное использование или же переработку, после которой вещи выглядят совершенно другим образом.

«Подруга выкладывает в инсту фешн видео, как она разрезает старый пиджак и делает из него дизайнерскую юбку, прославляя апсайклинг. Я вспоминаю, как в 90-х мама перешивала какие-то свои вещи, чтобы создать мне подобие школьной формы» (твит от 6 февраля 2021 года)

Aутлет om англ: outlet - магазин, где представлены один или несколько достаточно известных брендов.

«С 4 по 7 марта в ДК им. Кирова пройдёт выставкапродажа «АУТЛЕТ», на которой посетителей ждут большие скидки, акции, сезонные предложения и распродажи от компаний-участников со всех регионов России и других стран мира» (твит от 12 февраля 2021 года)

Однако столь же часто можно встретить и такие случаи, когда англицизм имеет русский аналог, который отбрасывается ради стилистического эффекта от использования англицизма, например: поясная сумка от англ: beltbag - это привычная поясная сумка, может быть кожаной или тканевой, закрывается на клапан или молнию, застегивается на талии.

«В этом году дизайнеры и стилисты отказались от идеи считать бельтбэг (поясная сумка) элементом исключительно спортивного стиля и сделали эту сумку одним из трендовых...» (твит от 28 июня 2019 года) - блогер использует бельтбэг из-за графической необычности. Эта комбинация необычности и неопределенности рассматривается как типичный признак языка рекламы, который обладает высокой экспрессивностью.
Брюки-кюлот om англ: culotte - легкие свободные брюки, расширяющиеся от бедра и элегантно превращающиеся в юбку.

«В НАЛИЧИИ КЮЛОТЫ! Доставка Укр почтой и Новой почтой! Стильные женские брюки-кюлоты от Зара (Испания). Высокая прорезиненная талия! Два боковых кармана. Приятная ткань! Отличное качество! Eсть два цвета, размеры уточняйте! 100\% хлопок. Цена 450 грн!» (твит от 31 января 2021 года) - блогер использует кюлот и брюки-кюлот для выражения вариации, чтобы избежать повторения слов в публицистических текстах.

Одежда свободного кроя от англ: oversize - как правило, выглядит на несколько размеров больще. При помощи вещей «оверсайз» легко создать стильный образ и скрыть то, что нужно скрыть.

«Стильные оверсайз худи для парней и девушек в разных иветах, есть все размеры» (твит от 18 февраля 2021 года) - блогер употребляет англицизм, в целях экономии, используя краткость слова «оверсайз».

Англицизмы играют важную роль в привлечении внимания и повышении престижа бренда: знание английского языка в современном обществе считается престижным. В свою очередь, рекламодатели, использующие в том или ином виде в рекламных сообщениях английский язык (английские слова, транслитерации, экзотизмы, композиты, аббревиатуры, графические и графические гибриды), хотят, чтобы рекламируемые бренды казались особо актуальными. Исследования показывают, что «странность» и «непонятность» иноязычных слов только усиливает уникальность и престиж рекламируемых товаров в глазах потенциальных покупателей. При этом рекламодатели не ставят перед собой задачу сделать текст понятным так как, не факт, что каждый носитель русского языка поймет иноязычные слова, например:

Каталог фотографий от англ: lookbook - это каталог фотографий, ключевых образов как, что и с чем носить из коллекции дизайнера или бренда.

«Симон Роша и H\&M показали лукбук совместной коллекции. В середине января Симон Роша анонсировала выпуск совместной коллекции с H\&M, которая еще до выхода получила статус главной коллаборации года» (твит от 9 февраля 2021 года) - блогер предпочитает языковую экономию, используя точные выражения, относящиеся к характерной черте языка СМИ.

Инфлюенсер om англ: influencer - человек, который ведет активную деятельность в социальных сетях и владеет вниманием, авторитетом большой аудитории подписчиков.

«Ребят я фуд-инфлюенсер. Моя подруга НЕНАВИДЕ- 
ЛА йогурт с черносливом. Пока я не дала ей его попробовать из МОЕЙ бутылки. На след день она купила себе литровый йогурт с черносливом. Мне ничего не стоит заставить вас полюбить сырой фарш» (твит от 6 февраля 2021 года) - блогер передаёт профессиональный колорит, придавая специальную компетенцию, точность и научность.

Ключевые образы в коллекции дизайнера от англ: guideline - это какая-нибудь яркая, запоминающаяся деталь, которая прослеживается во всей коллекции.

«Представляю вам логотипы для фансаб группы @ FsgBaby и для магазина из Китая, который открыла @Battlecruiser_a.Логотипы в одной манере выполнены в кратчайшие сроки! Это самые милые мои заказчики! У вас всегда есть возможность заказать у меня логотип или полноченный брендинг. Гайдлайн с описанием для вашего удобства в использовании» (твит от 7 сентября 2020 года) - блогер использует приём эффекта новизны англоязычных слов, которые менее известны в русском языке и еще в нем прочно не обосновались.
Обращаясь к высказыванию А.П. Сумарокова, который сказал: «Восприятие чужих слов, а особливо без необходимости, есть не обогащение, но порча языка» [Сумароков 1980]. Хотелось бы отметить, что, действительно, заимствования без меры засоряют нашу речь, делают ее не для всех понятной. Засорение русского языка жаргонизмами, иностранными словами, нецензурной бранью - вот проблема, которую рассматривает в тексте писатель.

Заимствования так легко внедряются в нашу жизнь, что мы воспринимаем их как свои собственные слова. Обилие иностранных слов в языке может привести к тому, что наша речь просто «утонет» в огромном количестве заимствований и потеряет свои корни, наступит лингвокологический кризис языка и речи, загрязнение языка газет и журналов. Поэтому, чтобы русский язык мог сохранить свою «изюминку», необходимо отказаться от некоторых бесполезных иностранных слов. Актуальность выбранной нами темы очевидна: лингвокология языка и речи - важнейшая проблема современного русского общества, выходящая на уровень сохранения культуры человечества в целом.

\section{ЛИТЕРАТУРА}

1. Белозерова Н.Н., Лабунец Н.В. Эколингвистика: в поисках методов исследования // Тюмень: Изд-во Тюменского гос. ун-та, 2012. С. 256.

2. Бернацкая А.А. 0 трех аспектах экологии языка // Вестник Красноярского государственного университета. Серия: гуманитарные науки. Красноярск, 2003. № 4. C. 122-124.

3. Жданова 0.П. Лингвоэкологический портрет толкового словаря начала XXI века // Экология языка и коммуникативная практика. 2013. № 1. С. 54-72.

4. Дьяков А.И. Словарь англицизмов русского языка [Электронный ресурс]. URL: https://www.anglicismdictionary.ru (дата 0бращения: 18.02.2021).

5. Ионова С.В. Основные направления эколингвистических исследований: зарубежный и отечественный опыт // Вестник Волгоградского государственного университета. Сер. 2. Языкознание. 2010. № 1. С. 86-93.

6. Лингвоэкологический аспект кодификационных и нормализационных процессов // Лингвистика и перевод: сб. науч. Статей: отв. ред. И.М. Нетунаева, А.М. Поликарпов: ИздВо Архангельск: ИПЦ САФУ, 2013. Вып. 2. С. 38-47.

7. Сидоренко Л.П., Гаврилова Н.Г. Необходимость «экологии языка» как естественное следствие развития российского общества // Вестник Чувашского университета. С. 107.

8. Солодовникова Н.Г., Шаховский В.И. Экологичность стилистики публичного общения // Медиаскоп: электронный научный журнал Факультета журналистики МГУ им. М.В. Ломоносова. 2012. Вып. [Электронный ресурс]. URL: http://mediascope.ru/node/1117 (дата обращения: 14.02.2021).

9. Сумароков А.П. Письма в кн.: Письма русских писателей XVIII века. Л., 1980 С. 412.

10. Экология языка - чистота речи - нравственность помыслов: психологический аспект // М.Ю. Чернышов, Т.Р. Мигунова, А.М. Журавлева, Г.Ю. Чернышева. С. 83-84.

11. [Электронный ресурc]. URL: https://www.lays.ru (дата обращения: 18.02.2021). 